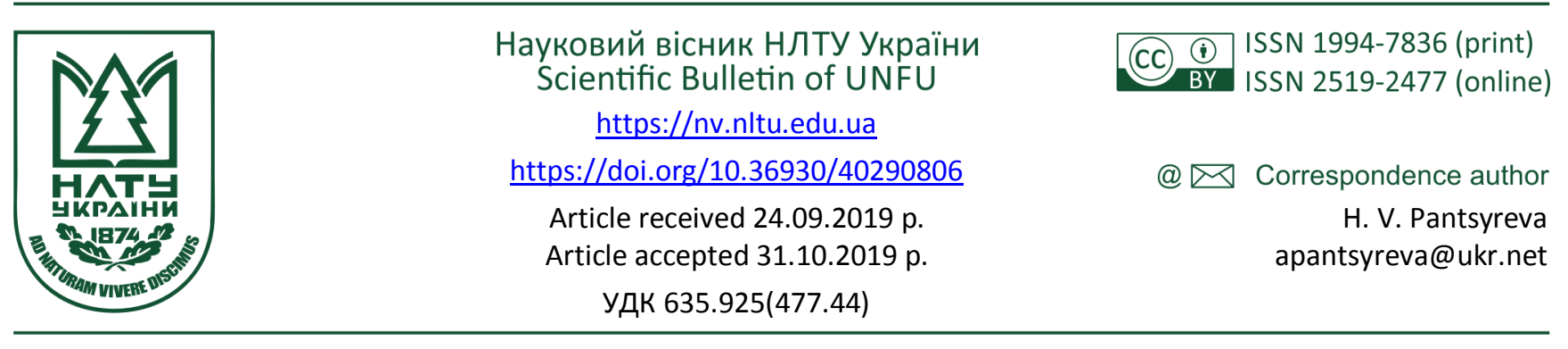

Г. В. Панцирева, О. О. Миколюк, В. В. Семчук

Вінницький національний аграрний університет, м. Вінниия, Украйна

\title{
СУЧАСНИЙ СТАН КОЛЕКЦІЇ ПІВОНІЙ НА БАЗІ БОТАНІЧНОГО САДУ "ПОДІЛЛЯ" ВІННИЦЬКОГО НАЦІОНАЛЬНОГО АГРАРНОГО УНІВЕРСИТЕТУ
}

Висвітлено результати дослідження перспективності вирощування 32 сортів та гібридів півонії в умовах ботанічного саду "Поділля" ВНАУ, м. Вінниця, у перший рік вегетації. Досліджено декоративні властивості видів, сортів та гібридів трав'яних видів півоній. Проаналізовано наукові публікації сортів та гібридів півонії молочноквіткової, лікарської та тонколистої. Представлено облік видового та сортового складу представників роду Paeonia L. за датою появи сходів, приростом вегетативної маси, початком появи бутонів, забарвленням стебла, кількістю листків та формою куща в перший рік вегетації. Встановлено, що всі досліджувані сорти/гібриди вітчизняної та закордонної (видові та японські форми) селекції викликають інтерес як потенційно цінні об'єкти для поповнення асортименту вітчизняних декоративних рослин та є перспективними для поліпшення стану парків, скверів, садків зони Поділля. Враховуючи високі декоративні якості цих видів та широкі можливості їх застосування, квітниково-декоративні рослини представників трав'яних видів Paеопia L. становлять значний інтерес для декоративного садівництва, зокрема квітникарства, та для поповнення асортименту декоративних культур нашої держави. Також дослідженнями визначено природні можливості представників трав'яних видів Paеопia L., пластичність до зміни їх життєвої форми, високу якість за сукупністю ознак, що визначають їхню декоративність, характеризує досліджувані рослини як джерело для інтродукції, а також збагачення асортименту декоративних культур в Україні. Порівняння отриманих результатів із характеристикою сортів, представленою оригінатором, показали збіг сортових ознак за всіма показниками. Результати досліджень будуть використані для поповнення наявної колекції півоній на базі ботанічного саду "Поділля" ВНАУ, практичної діяльності студентів спеціальності 206 "Садово-паркове господарство" та наукових працівників.

Ключові слова: Paeonia L.; сорт; гібрид; напрям використання; зона вирощування; фенологічні спостереження; біоморфологічні показники.

Вступ. Півонії займають провідне місце серед багаторічників, які здатні перезимовувати у відкритому грунті. Висока декоративність, довговічність та можливість широкого використання в декоративному садівництві, екологічна пластичність не тільки видів, але i більшості сортів, дає змогу вирощувати дані рослини в різних кліматичних зонах України (Sakhatska, 2012).

У галузі садівництва рід Paeonia L. представлений як значною кількістю видів (40), так і багатим сортовим асортиментом, що становить більше як 5000 сортів. Водночас, виявлено, що до асортименту декоративних культур України входить 5 видів, тобто менше як $2 \%$ сортів (Sakhatska, 2012; Mazur, Prokopchuk \& Pantsyreva, 2018). 3 практичного погляду всі досліджувані сорти та гібриди української та закордонної селекції викликають інтерес як потенційно цінні об'єкти для збагачення асортименту декоративних рослин України та $є$ перспективними для створення моносаду на базі Вінницького національного аграрного університету (Mazur, Pro-

kopchuk \& Pantsyreva, 2018; Berenzher, Pol \& Hrassar, 2004).

На базі ботанічного саду "Поділля" ВНАУ представлено сорти та гібриди трав'яних видів півонії. В умовах сьогодення трав'яні півонії є одними 3 найбільш легко вирощуваних витривалих багаторічних рослин. Довговічні та надійні, півонії можна легко вирощувати до 100 i більше років. Будучи трав'яним багаторічником, у цієї групи півонії щорічний приріст стебла продовжується впродовж весни та літа. Відмирання стеблової маси відбувається пізно восени, залишаючись у спокої протягом зимового сезону (American Peony Society, 2019). Дослідження нових сортів та спостереження за їх розвитком дасть змогу значно розширити використання культури півонії в озелененні та збагатити культивовану флору зони Поділля та України загалом.

Аналіз останніх досліджень і публікацій. У родині Півонієвих всього один рід Півонія, в якому існує три групи - деревовидні, трав'яні та Іто-півонії, що пред-

\section{Інформація про авторів:}

Панцирева Ганна Віталіївна, канд. с.-г. наук, ст. викладач, кафедра садово-паркового господарства, садівництва та виноградарства. Email: apantsyreva@ukr.net; https://orcid.org/0000-0002-0539-5211

Миколюк Олена Олександрівна, магістрантка, кафедра садово-паркового господарства, садівництва та виноградарства. Email: apantsyreva@ukr.net

Семчук Василь Васильович, магістрант, кафедра садово-паркового господарства, садівництва та виноградарства. Email: apantsyreva@ukr.net

Цитування за ДСТУ: Панцирева Г. В., Миколюк О. О., Семчук В. В. Сучасний стан колекції півоній на базі ботанічного саду "Поділля" Вінницького національного аграрного університету. Науковий вісник НлТУ України. 2019, т. 29 , № 8. С. 46-50.

Citation APA: Pantsyreva, H. V., Mykoluk, O. O., Semchuk, V. V. (2019). The modern state of peony collection on the basis of Podillya botanical garden in Vinnytsya national agrarian university. Scientific Bulletin of UNFU, 29(8), 46-50.

https://doi.org/10.36930/40290806 
ставляють собою гібрид перших і других. Деревовидні півонії переважно походять з Китаю і Японії. Трав'яні півонії $є$ найпоширеніші. Вони трапляються в Середземномор'ї, Азії, Європі, Північній Америці (Mazur et al., 2019; Chervona knyha Ukrainy, 2019).

Півонії поширені в середньому поясі. Здебільшого це багаторічні трав'яні рослини, рідше - напівкущі або кущі. У трав'яних видів взимку надземна частина повністю відмирає; у півонії деревовидної впродовж року зберігається характерний розкидистий кущ. У напівкущів ступінь обмерзання залежить від кліматичних умов, а також від місця зростання. В умовах середньої широти в них дерев'яніє лише нижня частина пагонів, причому це ніяк не впливає на цвітіння рослини. Тибетська форма півонії жовтої (P. lutea) морозостійка і може зимувати без укриття (Kataloh, 2019; Hrodzinskyi, 1992).

В Україні природно ростуть два трав'яних види: півонія вузьколиста (Paeonia tenuifolia), що трапляється в Лісостепу, Степу та Криму, а також півонія кримська (Paeonia daurica) (Sydoruk, T. M, 2007).

Півонії вирощували в садах Китаю з 536 року, де з'явилися і перші сорти. Видатними селекціоерами світового масштабу є Н. Лімон, Д. Калот, Ф. В. Лемоне, А. Дессерт, Кроус, Ч. Вердіер, А. Мілез. І сьогодні такі їхні сорти набули значної популярності: Festiva Maxima, Edulis Superba, Philomele, Mons. Jules Elie, Felix Crousse, Albatre, Le Cygne, Mont Blanc, Sarah Bernhard, Solange та інші, які свого часу були інтродуковані в різні країни світу, зокрема і в Україну (Berenzher, Pol \& Hrassar, 2004; Mazur et al., 2019; Chervona knyha Ukrainy, 2019; Mazur, Prokopchuk \& Pantsyreva, 2018).

У нашій країні селекцію півонії розпочали у 50 -х роках минулого століття вчені-квітникарі А. А. Сосновець та I. C. Краснова. Також селекційну роботу веде Київський Ботанічний сад ім. Гришка. Вчений-селекціонер В. Ф. Горобець створив багато сортів: Хохлома, Ірокез, Червоний Оксамит, Червоні Вітрила, Офелія, Ювілей Києва, Жемчужна Розсип, Скарбниця і багато інших, які є основою для народної селекції (Kataloh, 2019; Маzur et al., 2019).

Використання міжвидової гібридизації дало змогу створити сорти 3 дуже ранніми термінами цвітіння та різноманітним забарвленням (червоного, коралового, вишневого, лавандового кольорів). Залежно від використання, півонії поділяють на паркові, зрізувальні та універсальні (Sakhatska, 2012; Mazur, Prokopchuk \& Pantsyreva, 2018; American Peony Society, 2019; Chervona knyha Ukrainy, 2019). Висока морозостійкість цих рослин дає змогу вирощувати їх практично по всій території України. У природі трав'яні півонії зростають на будь-яких відкритих сонцю місцях - на лісових галявинах, у степах, на луках і гірських схилах. Немає їх тільки там, де занадто багато вологи (Chervona knyha Ukrainy, 2019).

Мета та завдання дослідження. Дослідити та проаналізувати декоративні характеристики та здатність до адаптації сортів української та світової селекції Paeonia L. в агрокліматичних умовах м. Вінниця. Дослідження виконували з метою збагачення декоративної флори ботанічного саду "Поділля" екземплярами півоній, які здатні проявити свої найкращі якості в цій місцевості. Згідно з метою, основним завданням було виявлення найбільш перспективних сортів/гібридів для створення моносаду півоній та подальше спостереження за цими рослинами.

Об'єкт дослідження - морфобіологічні особливості видів роду Paeonia L. в умовах культури (ботанічний сад "Поділля" ВНАУ). Предмет дослідження - трав'янисті види роду Paeonia L. (родина Paeoniaceae Rudolphi). Результати досліджень використаємо для покращення умов існування наявних сортів та видів, а також пошуку інших екземплярів для розширення наявної флори.

Матеріал та методи дослідження. Матеріалом для досліджень є сорти, види та гібриди Paeonia L. як української, так і світової селекції (табл. 1).

Табл. 1. Асортимент представників роду Paeonia L. на базі експозиційної ділянки ботанічного саду "Поділля" ВНАУ

\begin{tabular}{|c|c|c|}
\hline \begin{tabular}{|l|}
$№$ \\
$3 / \Pi$ \\
\end{tabular} & Назва сорту/гібриду & Кількість, шт. \\
\hline 1 & China Maid & 2 \\
\hline 2 & Чарівник & 2 \\
\hline 3 & Heritage & 1 \\
\hline 4 & Triumph de Nord & 1 \\
\hline 5 & Корифей & 1 \\
\hline 6 & Малинова Ватра & 1 \\
\hline 7 & Антей & 2 \\
\hline 8 & Mahogany & 1 \\
\hline 9 & Diana Parks & 1 \\
\hline \begin{tabular}{|l|l|l}
10 & \\
\end{tabular} & Cherry Red & 1 \\
\hline 11 & Venus & 1 \\
\hline \begin{tabular}{|l|l}
12 & 0 \\
\end{tabular} & Сара Бернар & 1 \\
\hline \begin{tabular}{|l|l|}
13 \\
\end{tabular} & Reine Hortense & 1 \\
\hline 14 & Червоні Вітрила & 1 \\
\hline 15 & Світоч & 1 \\
\hline 16 & Ліхтарик & 1 \\
\hline \begin{tabular}{|l|l|}
17 & \\
17 &
\end{tabular} & Жемчужна Розсип & 1 \\
\hline 18 & Henry Bockstoce & 1 \\
\hline 19 & Mons. Jules Elie & 1 \\
\hline 20 & Seraphim & 1 \\
\hline 21 & Червоний Оксамит & 1 \\
\hline 22 & Rubra plena & 1 \\
\hline 23 & Tenifolia plena & 1 \\
\hline 24 & Тонколистий степовий & 1 \\
\hline 25 & Doreen & 2 \\
\hline 26 & Gay Paree & 2 \\
\hline 27 & Gold Standart & 2 \\
\hline 28 & Hit Parade & 1 \\
\hline \begin{tabular}{|l|}
29 \\
\end{tabular} & Moon of Nippon & 1 \\
\hline 30 & Neon & 1 \\
\hline \begin{tabular}{|l|}
31 \\
\end{tabular} & Philomele & 2 \\
\hline \begin{tabular}{|l|}
32 \\
\end{tabular} & Hot Chocolate & 2 \\
\hline
\end{tabular}

Дослідження проводили впродовж 2018-2019 рр. на базі архітектурно-експозиційної ділянки ботанічного саду "Поділля" Вінницького національного аграрного університету. Грунтово-кліматичні умови зони дослідження сприятливі для вирощування досліджуваного виду Paeonia L.

Результати дослідження та їх обговорення. Проаналізувавши ці сорти, та гібриди Paeonia L., встановлено, що досліджувані рослини добре підходять до агрокліматичних умов м. Вінниця. Асортимент роду Paeonia L. на експозиційній ділянці представлений у вигляді 32 сортів та гібридів, в тому числі української селекції, як: 'Корифей', 'Малинова Ватра', 'Антей' та ін., оригінатором яких є В. Ф. Горобець

Наявні екземпляри півоній було висаджено 5.11.2018 р. Наступної весни після насадження, півонії 
пізно та нерівномірно, появу бутонів спостерігали не на всіх рослинах (табл. 2), проте всі представники сформували характерний габітус куща зі здоровими пагонами та листям. Перші сходи з'явилися у: 'Чарівник' (05.04), 'Diana Parks' (08.04), 'Червоні Вітрила' (08.04), дещо пізніше зійшов 'Ліхтарик' (20.05). Згідно з програмою експериментальних досліджень, проводили лінійні вимірювання висоти півоній (табл. 3 ).

Так, найбільшим приростом рослин станом на 30.06 характеризувався гібрид закордонної селекції Gay Paree - 630 мм, дещо нижчі показники зафіксовано у рослин сорту Henry Bockstoce. Серед сортів вітчизняної селекції найбільші показники приросту рослин характерні для сорту Світоч, цей показник становить 340 мм (Pantsyreva, 2018).

Встановлено, що основними напрямами використання сортів та гібридів Paeonia L. є декоративний (озеленення, зріз) та лікарський. Рослини культивують зазвичай у квітниках і садах як декоративну, а в народній медицині використовують, окрім квіток, і кореневу систему півонії (Mazur, Prokopchuk \& Pantsyreva, 2018; Solonenko \& Vatamaniuk, 2016; Prokopchuk, 2017). Досліджувані представники Paeonia L. різняться за висотою, облиствленістю, формою куща (табл. 4).

Табл. 2. Фенологічні спостереження за Рaeonia L. на базі експозиційної ділянки ботанічного саду "Поділля" ВНАУ (середнс за 2018-2019 рр.)

\begin{tabular}{|c|c|c|c|c|}
\hline № $3 /$ П & Назва сорту/гібриду & Дата появи сходів & Забарвлення пагона & Поява бутонів \\
\hline 1 & China Maid & 15.04 & червоно-зелене & - \\
\hline 2 & Чарівник & 05.04 & червоно-зелене & - \\
\hline 3 & Heritage & 13.04 & червоно-зелене & - \\
\hline 4 & Triumph de Nord & 29.04 & червоно-зелене & - \\
\hline 5 & Корифей & 05.05 & червоно-зелене & - \\
\hline 6 & Малинова Ватра & 22.04 & червоно-зелене & 10.05 \\
\hline 7 & Антей & 15.04 & червоно-зелене & - \\
\hline 8 & Mahogany & 06.05 & зелене & - \\
\hline 9 & Diana Parks & 08.04 & червоно-зелене & - \\
\hline 10 & Cherry Red & 15.04 & червоно-зелене & 03.05 \\
\hline 11 & Venus & 06.05 & червоно-зелене & - \\
\hline 12 & Сара Бернар & 06.05 & червоно-зелене & - \\
\hline 13 & Reine Hortense & 22.04 & червоно-зелене & 10.05 \\
\hline 14 & Червоні Вітрила & 08.04 & зелене & 02.05 \\
\hline 15 & Світоч & 15.04 & червоно-зелене & 10.05 \\
\hline 16 & Ліхтарик & 20.05 & червоно-зелене & - \\
\hline 17 & Жемчужна Розсип & 06.05 & червоно-зелене & 10.05 \\
\hline 18 & Henry Bockstoce & 29.04 & зелене & 01.05 \\
\hline 19 & Mons. Jules Elie & 13.05 & червоно-зелене & - \\
\hline 20 & Seraphim & 15.04 & червоно-зелене & - \\
\hline 21 & Червоний Оксамит & 04.05 & червоно-зелене & 10.05 \\
\hline 22 & Rubra plena & 22.04 & зелене & 29.04 \\
\hline 23 & Tenifolia plena & 15.04 & зелене & 25.04 \\
\hline 24 & Тонколистий степовий & 06.05 & листя зелене, стебла червонуваті & - \\
\hline 25 & Doreen & 12.05 & червоно-зелене & 03.05 \\
\hline 26 & Gay Paree & 10.04 & червоно-зелене & 29.04 \\
\hline 27 & Gold Standart & 08.05 & червоно-зелене & 03.05 \\
\hline 28 & Hit Parade & 18.04 & червоно-зелене & 10.05 \\
\hline 29 & Moon of Nippon & 29.04 & зелене & - \\
\hline 30 & Neon & 20.04 & листя зелене, стебла червоні & 28.04 \\
\hline 31 & Philomele & 22.04 & листя зелене, стебла червонуваті & 03.10 \\
\hline 32 & Hot Chocolate & 15.04 & темно-червоне & 10.05 \\
\hline
\end{tabular}

Табл. 3. Приріст сортів і гібридів Раeоnia L. після появи сходів на базі експозиційної ділянки ботанічного саду "Поділля" ВНАУ, (середнс за 2018-2019 рр.)

\begin{tabular}{|c|l|c|c|c|c|c|c|c|c|c|}
\hline \multirow{2}{*}{$№$ з/п } & \multirow{2}{*}{ Назва сорту/гібриду } & \multicolumn{9}{|c|}{ Висота (мм) } \\
\cline { 3 - 11 } & & 08.04 & 15.04 & 22.04 & 29.04 & 06.05 & 13.05 & 20.05 & 27.05 & 03.06 \\
\hline 1 & & 3 & 4 & 5 & 6 & 7 & 8 & 9 & 10 & 11 \\
\hline 1 & China Maid & - & 5 & 10 & 60 & 135 & 180 & 230 & 250 & 250 \\
\hline 2 & Чарівник & 40 & 93 & 150 & 230 & 270 & 290 & 290 & 290 & 290 \\
\hline 3 & Heritage & - & 42 & 110 & 125 & 185 & 210 & 240 & 270 & 270 \\
\hline 4 & Triumph de Nord & - & - & - & 15 & 45 & 100 & 270 & 370 & 390 \\
\hline 5 & Корифей & - & - & - & - & 25 & 80 & 135 & 180 & 250 \\
\hline 6 & Малинова Ватра & - & - & 50 & 72 & 160 & 235 & 400 & 550 & 550 \\
\hline 7 & Антей & - & 35 & 110 & 185 & 260 & 305 & 320 & 325 & 330 \\
\hline 8 & Маһоgany & & - & - & - & 15 & 60 & 145 & 200 & 230 \\
\hline 9 & Diana Рarks & 10 & 62 & 75 & 85 & 100 & 110 & 120 & 120 & 120 \\
\hline 10 & Сherry Red & - & 36 & 95 & 110 & 190 & 265 & 345 & 400 & 470 \\
\hline 11 & Venus & - & - & - & - & 20 & 70 & 370 & 470 & 570 \\
\hline 12 & Сара Бернар & - & - & - & - & 35 & 90 & 110 & 180 & 250 \\
\hline 13 & Reine Ногtense & - & - & 4 & 100 & 255 & 500 & 520 & 580 & 580 \\
\hline 14 & Червоні Вітрила & 20 & 75 & 150 & 200 & 350 & 550 & 550 & 550 & 430 \\
\hline
\end{tabular}




\begin{tabular}{|c|l|c|c|c|c|c|c|c|c|c|}
\hline \multicolumn{1}{|c|}{2} & 3 & 4 & 5 & 6 & 7 & 8 & 9 & 10 & 11 \\
\hline 15 & Світоч & - & 30 & 115 & 195 & 260 & 350 & 340 & 340 & 340 \\
\hline 16 & Ліхтарик & - & - & - & - & - & - & 70 & 120 & 200 \\
\hline 17 & Жемчужна Розсип & - & - & - & - & 45 & 150 & 260 & 300 & 330 \\
\hline 18 & Неnry Bockstoce & - & - & - & 40 & 180 & 300 & 520 & 600 & 600 \\
\hline 19 & Mons. Jules Elie & - & - & - & - & - & 50 & 260 & 300 & 300 \\
\hline 20 & Seraphim & - & 15 & 75 & 90 & 130 & 160 & 170 & 185 & 185 \\
\hline 21 & Червоний Оксамит & - & - & - & - & 70 & 160 & 240 & 250 & 250 \\
\hline 22 & Rubra plena & - & - & 55 & 105 & 220 & 300 & 390 & 390 & 390 \\
\hline 23 & Tenifolia plena & - & 55 & 80 & 90 & 130 & 150 & 180 & 190 & 190 \\
\hline 24 & Tонколистий степовий & - & - & - & - & 60 & 100 & 160 & 200 & 240 \\
\hline 25 & Doreen & - & - & - & - & - & 70 & 300 & 450 & 450 \\
\hline 26 & Gay Paree & - & 63 & 135 & 200 & 300 & 450 & 570 & 590 & 630 \\
\hline 27 & Gold Standart & - & - & - & - & - & 80 & 320 & 480 & 590 \\
\hline 28 & Нit Parade & - & - & 40 & 105 & 250 & 400 & 445 & 455 & 455 \\
\hline 29 & Моon of Nipроп & - & - & - & 20 & 150 & 250 & 270 & 300 & 330 \\
\hline 30 & Neon & - & 45 & 120 & 150 & 200 & 260 & 320 & 330 & 330 \\
\hline 31 & Philomele & - & - & 7 & 65 & 90 & 125 & 470 & 475 & 475 \\
\hline 32 & Hot Chocolate & - & 5 & 45 & 70 & 210 & 350 & 530 & 550 & 550 \\
\hline
\end{tabular}

Табл. 4. Морфометричні ознаки сортів та гібридів Paeonia L. на базі експозиційної ділянки ботанічного саду "Поділля" ВНАУ (середне за 2018-2019 рр.)

\begin{tabular}{|c|c|c|c|c|}
\hline № 3/ח & Назва сорту/гібриду & Висота куща, мм & Кількість листків, шт. & Форма куща \\
\hline 1 & China Maid & 250 & 3 & куляста \\
\hline 2 & Чарівник & 290 & 4 & куляста \\
\hline 3 & Heritage & 270 & 4 & куляста \\
\hline 4 & Triumph de Nord & 390 & 6 & куляста \\
\hline 5 & Корифей & 250 & 7 & компактна куляста \\
\hline 6 & Малинова Ватра & 550 & 8 & видовжена \\
\hline 7 & Антей & 330 & 19 & куляста \\
\hline 8 & Mahogany & 230 & 6 & куляста \\
\hline 9 & Diana Parks & 120 & 4 & куляста \\
\hline 10 & Cherry Red & 470 & 8 & куляста \\
\hline 11 & Venus & 570 & 5 & куляста \\
\hline 12 & Сара Бернар & 250 & 5 & куляста \\
\hline 13 & Reine Hortense & 580 & 12 & куляста \\
\hline 14 & Червоні Вітрила & 430 & 19 & видовжена \\
\hline 15 & Світоч & 340 & 11 & куляста \\
\hline 16 & Ліхтарик & 200 & 9 & компактна куляста \\
\hline 17 & Жемчужна Розсип & 330 & 18 & куляста \\
\hline 18 & Henry Bockstoce & 600 & 9 & видовжена \\
\hline 19 & Mons. Jules Elie & 300 & 8 & куляста \\
\hline 20 & Seraphim & 185 & 3 & куляста \\
\hline 21 & Червоний Оксамит & 250 & 13 & куляста \\
\hline 22 & of. Rubra plena & 390 & 15 & куляста \\
\hline 23 & Tenifolia plena & 190 & 25 & куляста \\
\hline 24 & Червоний 1 & 250 & 8 & куляста \\
\hline 25 & Червоний 2 & 260 & 10 & куляста \\
\hline 26 & Тонколистний степовий & 240 & 4 & куляста \\
\hline 27 & Doreen & 450 & 9 & куляста \\
\hline 28 & Gay Paree & 630 & 22 & куляста \\
\hline 29 & Gold Standart & 590 & 12 & куляста \\
\hline 30 & Hit Parade & 455 & 14 & куляста \\
\hline 31 & Moon of Nippon & 330 & 17 & куляста \\
\hline 32 & Neon & 330 & 19 & куляста \\
\hline 33 & Philomele & 475 & 15 & куляста \\
\hline 34 & Hot Chocolate & 550 & 29 & куляста \\
\hline
\end{tabular}

3 усіх досліджуваних культиварів найбільшу висоту мають 'Gay Paree' та 'Henry Bockstoce' (630 мм та 600 мм). Найнижчими є 'Diana Parks' та 'Seraphim', висота цих рослин становить відповідно 120 см та 185 см. Більшість кущів мають кулясту форму, проте у 'Henry Bockstoce', 'Червоні Вітрила' та 'Малинова Ватра' в перший рік вегетації спостерігали видовжену форму. Найнижчою облиствленістю характеризується 'China Maid', найбільш густооблиствлені - 'Tenifolia plena' та 'Hot Chocolate'.
Висновки. Внаслідок проведених досліджень виявлено, що всі сорти, види та гібриди півоній (40 культиварів) придатні для вирощування на базі експозиційної ділянки ботанічного саду "Поділля" ВНАУ, м. Вінниця. Усі представники різняться між собою за висотою (від 120 мм до 630 мм), формою (куляста, компактно куляста, видовжена) куща, появою сходів (від 5.04 до 20.05), проте всі вони ідеально підходять для застосування у ландшафтному дизайні. 


\section{Перелік використаних джерел}

American Peony Society. (2019). Herbaceous Peonies. Retrieved from: https://americanpeonysociety.org/learn/herbaceous-peonies/

Berenzher, A., Pol, H., \& Hrassar, E. (2004). Entsyklopedyia lekarstvennblkh rastenyi. Ryderz daidzhest, 351 p. [In Russian].

Chervona knyha Ukrainy. (2019). Pivoniievi (Paeoniaceae). Retrieved from: https://redbook-ua.org/category/paeoniaceae/. [In Ukrainian].

Hrodzinskyi, A. M. (1992). Likarski roslyny: entsyklopedychnyi dovidnyk. Kiev, 544 p. [In Ukrainian].

Kataloh. (2019). Kataloh sortiv roslyn, prydatnykh dlia poshyrennia $v$ Ukraini na 2018 rik (vytiah), 400 p. [In Ukrainian].

Mazur, V. A., Pantsyreva, H. V., Mazur, K. V., \& Monarkh, V. V. (2019). Ecological and biological evaluation of varietal resources Paeonia L. in Ukraine. Acta Biologica Sibirica, 5(1), 141-146. https://doi.org/10.14258/abs.v5.i1.5350

Mazur, V. A., Prokopchuk, V. M., \& Pantsyreva, H. V. (2018) Perspektyvnist stvorennia kolektsii pivonii na bazi botanichnoho sa$d u$ "Podillia" Vinnytskoho natsionalnoho ahrarnoho universytetu. VNAU, 14 p. [In Ukrainian].

Mazur, V. A., Prokopchuk, V. M., \& Pantsyreva, H. V. (2018). Primary introduction assessment of decorative species of the lupinus generation in Podillya. Scientific Bulletin of UNFU, 28(7), 40-43. https://doi.org/10.15421/40280708

Pantsyreva, H. V. (2018). Doslidzhennia sortovykh resursiv travianykh vydiv Paeonia L. v Ukraini. Scientific Bulletin of UNFU, 28(8), 74-78. https://doi.org/10.15421/40280815

Prokopchuk, V. M. (2017). Pervynna introduktsiina otsinka sortiv Antirrhinum Majus v umovakh biostatsionaru Vinnytskoho natsionalnoho ahrarnoho universytetu. (Ser. Silske hospodarstvo ta lisvnytstvo). Zbirnyk naukovykh prats VNAU, 7(1), 113-120. [In Ukrainian].

Sakhatska, I. M. (2012). Vstanovlennia zhyrnokyslotnoho skladu korenevyshch z koreniamy pivonii likarskoi sortiv "Alba Plena" ta "Rosea Plena". Ukrainskyi medychnyi almanakh, 15(1), 139-140. [In Ukrainian].

Solonenko, V. I., \& Vatamaniuk, O. V. (2016). Klasyfikatsiia topiarnykh form v sadovo-parkovomu budivnytstvi. (Ser. Silske hospodarstvo ta lisvnytstvo). Zbirnyk naukovykh prats VNAU, 3, 200209. [In Ukrainian].

Sydoruk, T. M. (2007). Travianysti bahatorichni roslyny vidkrytoho gruntu Natsionalnoho dendroparku "Sofiivka". Uman: UVPP, (pp. 115-122). [In Ukrainian].

H. V. Pantsyreva, O. O. Mykoluk, V. V. Semchuk Vinnytsia National Agrarian University, Vinnytsia, Ukraine

\section{THE MODERN STATE OF PEONY COLLECTION ON THE BASIS OF PODILLYA BOTANICAL GARDEN IN VINNYTSYA NATIONAL AGRARIAN UNIVERSITY}

Peonies occupy a leading position among perennials that can overwinter in open ground. High decorativity, durability and possibility of widespread use in ornamental horticulture, ecological plasticity of both species and most of varieties enable growing these plants in different climatic zones of Ukraine. In the field of horticulture, the genus Paeonia L. is represented by both a large number of species (40) and a rich assortment of more than 5000 varieties. At the same time, it is found that the range of decorative cultures of Ukraine includes 5 species, i.e. less than $2 \%$ of varieties. From a practical point of view, all the studied varieties and hybrids of Ukrainian and foreign breeding are of interest as potentially valuable objects for the enrichment of the ornamental plant of Ukraine and are promising for the creation of a monosade on the basis of Vinnytsia National Agrarian University. Varieties and hybrids of herbaceous peony species are presented on the basis of the Podillya Botanical Garden. In today's conditions, herbaceous peonies are one of the most easily grown durable perennial plants. Durable and reliable, peonies can be easily grown for up to 100 years or more. As herbaceous perennial, in this group of peonies the annual growth of the stalk continues during the spring and summer. The results of the study of the prospects of growing 32 varieties and hybrids of peonies in the conditions of the Podillya Botanical Garden of VNAU, Vinnytsia, during the first year of vegetation. The decorative properties of species, varieties and hybrids of herbaceous peony species have been investigated. The authors have analysed scientific publications of varieties and hybrids of peony milkweed, medicinal and thin-leafed. The account of the species and varietal composition of representatives of the genus Paeonia L. by date of emergence of seedlings, growth of vegetative mass, onset of buds, stem colour, number of leaves and shrub shape in the first year of vegetation is presented. It is established that all the studied varieties/hybrids of domestic and foreign (species and Japanese forms) breeding are of interest as potentially valuable objects for replenishing the range of domestic ornamental plants and are promising for improving the condition of parks, squares, and gardens of the Podillya area. Considering high decorative qualities of these species and the wide possibilities of their application, flower and ornamental plants of representatives of herbaceous species of Paeonia L. are of great interest for ornamental horticulture, in particular floriculture and to supplement the range of decorative crops of our country. The research also identified the natural possibilities of representatives of herbaceous species of Paeonia L., plasticity to change their life form, high quality on the set of characteristics that determine their ornamental characteristics of the studied plants, as a source for introduction, as well as the enrichment of the range of ornamental crops in Ukraine. Thus, the study of representatives of the genus Paeonia L. for landscaping will significantly expand the range of ornamental plants and enrich the cultivated flora of Podillia and Ukraine as a whole. Comparison of the results obtained with the characteristics of the varieties presented by the originator showed the coincidence of varietal characteristics in all indicators. The research results will be used to replenish the existing collection of peonies on the basis of the Podillya Botanical Garden of VNAU and the practical activities of students of the specialty 206 Landscape gardening and scientists.

Keywords: Paeonia L.; variety; hybrid; direction of use; cultivation zone; phenological observations; biomorphological parameters. 